\title{
A New European Editorial Office
}

In December, 2000, the European office of Pediatric Research moved from the Karolinska Institute in Stockholm to the Hôpital Robert Debré in Paris. This is in keeping with our journal's policy of moving each of the two (North American and European) editorial offices, every five years. Professor Jean-Christophe Mercier is the new European Chief Editor, replacing Professor Hugo Lagercrantz. Professor Mercier has appointed an outstanding group of internationally recognized clinicianscientists to serve as the journal's European Editors.

Professor Lagercrantz and his editorial colleagues in Stockholm have done an excellent job in contributing to the continuing development of our journal and to our efforts to maintain and promote the highest standard of scientific publication. Professor Lagercrantz has carried out his editorial duties effectively, while remaining committed to his many responsibilities as Head of the Neonatal program at the Karolinska Hospital and his own scientific research. Personally, it has been a great pleasure to work with Professor Lagercrantz because of his valuable scientific opinions and goals, and his commitment to Pediatric Research.

Professor Mercier is a member of the Division of Pediatric Intensive Care at the Hôpital Robert Debré. His research studies have been extensive and most recently have focused on endothelial function in the pulmonary circulation. He has been a senior member of the French and European Societies for Critical Care Medicine and of the French Society of Pediatric Research, for which he has been President.

The new team of European Editors hold academic appointments at the University of Paris. Clinical appointments are in either Hôpital Robert Debré, Hôpital Les Enfantes Malades or Hôpital Cochin which belong to the Assistance Publique-Hôpitaux de Paris network. The European Editors include:

Dr. Jacques Bourbon, Director of Research and Head of the team "Lung Ontogenesis" at the Cell Biology Center of the CNRS, INSERM Unit 319.

Dr. Paul Czernichow, Professor; Head of the Pediatric Endocrinology and Diabetology Unit, Hôpital Robert Debré; Director of the INSERM 458 Unit on pancreatic development.

Dr. Anh Tuan Dinh-Xuan, Associate Professor, Division of Physiology at Hôpital Cochin and Director of the Research Laboratory on Pulmonary Hypertension.

Dr. Philippe Evrard, Professor and Chief of Pediatric Neurology and Metabolic Diseases, Hôpital Robert Debré and Director of the
Research Laboratory in Developmental Neurosciences, INSERM E9935.

Dr. Claude Gaultier, Professor of Physiology and Director of the Pediatric Physiology Department, Hôpital Robert Debré.

Dr. Pierre Gressens, Assistant Professor, Division of Pediatric Neurology and Metabolic Diseases, Hôpital Robert Debré; Senior Scientist in the Research Laboratory in Developmental Neurosciences, INSERM E9935.

Dr. Jean Pierre Hugot, Assistant Professor, Division of Paediatric Gastroenterology and Nutrition, Hôpital Robert Debré; Senior Scientist in genetics of intestinal diseases.

Dr. Arnold Munnich, Professor of Genetics, Head of the Department of Genetics, Hôpital des Enfants-Malades; Director of the INSERM Unit-393 on genetic diseases.

Dr. Daniel Sidi, Associate Professor, Division of Pediatric Cardiology, Hôpital des Enfants Malades; Senior Research Scientist in Cardiac Development.

In the past two years, there have been many changes in Pediatric Research, including the introduction of new sections and the journal's availability on-line at www.pedresearch.org. In the coming year, we will move into electronic manuscript management, with the goal of a paperless system, whereby all manuscript submissions and reviews will be carried out electronically . It is our goal to reduce the "turnaround-time" from receipt of manuscript to publication. In this day of rapid communication and tremendous pace of scientific advancement, it is important for our journal to support our authors by rapid, peer-reviewed processing and publication of manuscripts.

In the coming year we will continue to publish new, original research and review manuscripts of the highest scientific merit. These will reflect the broad field of pediatric research. Professor Mercier and his editorial colleagues enthusiastically endorse this continuing mandate and have pledged to work together with us in advancing Pediatric Research as a major voice in the reporting of research in childhood disease and human development.
Alvin Zipursky Editor-in-Chief 